\title{
PENINGKATAN HASIL BELAJAR DAN KETERAMPILAN PROSES SAINS SISWA MELALUI PENGGUNAAN LKPD BERBASIS INKUIRI PADA MATERI STRUKTUR DAN FUNGSI JARINGAN TUMBUHAN
}

\author{
Rini Syahrayni Hasibuan', Cicik Suriani² \\ 'MAN 2 Model Medan, Jl. Willem Iskandar No.7A, Medan Tembung 20222 \\ 2Jurusan Biologi FMIPA Universitas Negeri Medan, Jl. Willem Iskandar Pasar V, Medan Estate 20221 \\ 'email: rinisyahraynihasibuan@yahoo.co.id.
}

\begin{abstract}
ABSTRAK
Penelitian ini bertujuan untuk mengetahui peningkatan hasil belajar dan keterampilan proses sains siswa melalui penggunaan LKPD berbasis inkuiri pada materi struktur dan fungsi jaringan tumbuhan di MAN 2 Model Medan. Jenis penelitian ini ada Penelitian Tindakan Kelas (PTK). Desain penelitian menggunakan model Kemmis dan MC.Taggart yang terdiri dari empat komponen yaitu: "perencanaan, implementasi/pelaksanaan tindakan, observasi/pengamatan dan refleksi. Subjek penelitian adalah siswa kelas XI IPA 2 MAN 2 Model Medan Tahun Pembelajaran 2018/2019. Objek penelitian ini berupa hasil belajar siswa dalam ranah kognitif dan keterampilan proses sains pada materi Struktur dan Fungsi Jaringan Tumbuhan dengan menerapkan LKPD berbasis inkuiri. Hasil penelitian ini adalah penggunaan LKPD berbasis inkuiri dapat meningkatkan hasil belajar Biologi siswa di kelas XI IPA2 MAN 2 Model Medan T.P 2018/2019. Siswa yang sudah mencapai KKM pada siklus I 38,10\% siswa dengan nilai rata-rata 75,5. Siswa yang sudah mencapai KKM pada siklus II 85,71\%, dengan nilai rata-rata 93,8. Penggunaan LKPD berbasis inkuri dapat meningkatkan keterampilan proses sains siswa (mengamati, bertanya, memprediksi, mengkomunikasi dan menyimpulkan) pada kegiatan pembelajaran Biologi di kelas XI IPA2 MAN 2 Model Medan.
\end{abstract}

Kata kunci: Hasil belajar, Inkuiri, keterampilan proses sains, LKPD

\section{ABSTRACT}

This study aims to determine the increase in learning outcomes and science process skills of students through the use of inquiry-based LKPD on material structure and function of plant tissue in the Medan MAN 2 Model. This type of research is Classroom Action Research (CAR). The research design uses the Kemmis and MC models. The Taggart consists of four components, namely: "planning, implementing / implementing actions, observing / observing and reflecting. The research subjects were students of class XI IPA 2 MAN 2 Medan Model Learning Year 2018/2019. The object of this research is in the form of student learning outcomes in the cognitive domain and science process skills in the material Structure and Function of Plant Networks by applying inquiry-based LKPD. The results of this study are the use of inquiry-based LKPD can improve Biology learning outcomes of students in class XI IPA2 MAN 2 Model Medan T.P 2018/2019. Students who have reached KKM in cycle $138.10 \%$ of students with an average score of 75.5. Students who have reached KKM in the second cycle $85.71 \%$, with an average score of 93.8. The use of inkuri-based LKPD can improve students' science process skills (observing, asking, predicting, communicating and concluding) in Biology learning activities in class XI IPA2 MAN 2 Model Medan.

Keywords: Inquiry, learning outcomes, science process skills, worksheet

\section{PENDAHULUAN}

Kemampuan guru dalam melaksanakan kegiatan inti pembelajaran merupakan hal yang paling berpengaruh dalam meningkatkan hasil belajar siswa. Salah satu faktor yang mempengaruhi keberhasilan belajar tersebut adalah bahan ajar yang digunakan dalam proses belajar. Salah satu jenis bahan ajar adalah Lembar Kerja Peserta Didik (LKPD). Karakteristik dalam mempelajari sains adalah berupaya menggali gejala dan proses kehidupan dari lingkungan. Biologi sebagai bagian dari sains, dalam pembelajarannya tidak dapat dilepaskan dari hakikat sains sebagai produk dan proses. Maka dari itu, sebagai pengetahuan yang terstruktur, pembelajaran sains menurut Carin 
(1997), diperoleh melalui proses aktif, dinamis dan eksploratif dari kegiatan induktif.

Pembelajaran sains mengacu pada teori belajar konstruktivisme yang berpandangan bahwa belajar merupakan kegiatan membangun pengetahuan yang dilakukan sendiri oleh siswa berdasarkan pengalaman yang dimiliki sebelumnya. Oleh karena itu, kegiatan seperti observasi, pengukuran dan percobaan merupakan langkah penting dalam mempelajari Biologi. Untuk benarbenar dapat memahami materi dalam mata pelajaran Biologi dibutuhkan LKPD berbasis pendekatan sains yakni berbasis inkuiri. LKPD tersebut dapat meningkatkan kemampuan proses sains seperti observasi, memprediksi, pengukuran, dan pengelompokan yang sangat membutuhkan pengalaman langsung siswa dalam eksplorasi dan penyelidikan.

Rustaman (2005), mengemukakan bahwa belajar menjadi bermakna bagi siswa apabila mereka mendapat kesempatan untuk mengajukan pertanyaan, melaksanakan penyelidikan, mengumpulkan data, membuat kesimpulan dan berdiskusi (scientific inquiry). Hasil belajar Biologi siswa kelas XI IPA2 MAN 2 Model Medan pada materi di awal semester ganjil 2018/2019 belum seperti yang diharapkan, banyak yang belum mencapai nilai KKM yang ditetapkan dalam MGMP di MAN 2 Model Medan yaitu 85 dan begitu juga dengan keterampilan sainsnya, diantaranya masih banyak siswa yang tidak mau/malas bertanya dan tidak bisa mengajukan dugaan/prediksi. Berdasarkan deskripsi permasalahan di atas, maka tujuan dari penelitian ini adalah: (a) Untuk mengetahui peningkatan hasil belajar siswa pada materi Struktur dan Fungsi Jaringan Tumbuhan dengan penggunaan LKPD berbasis inkuiri di kelas XI IPA2 MAN 2 Model Medan Tahun Pembelajaran 2018/2019. (b) Untuk mengetahui keterampilan proses sains siswa pada materi Struktur dan Fungsi Jaringan Tumbuhan dengan menggunakan LKPD berbasis inkuiri dikelas XI IPA2 MAN 2 Model Medan Tahun Pembelajaran 2018/2019.

\section{METODE PENELITIAN}

Subjek penelitian adalah siswa kelas XI IPA2 MAN 2 Model Medan T.P 2018/2019. Objek dalam penelitian ini adalah hasil belajar siswa dalam ranah kognitif dan keterampilan proses sains pada materi Struktur dan Fungsi Jaringan Tumbuhan dengan menerapkan LKPD berbasis inkuiri.

Jenis penelitian adalah Penelitian

Tindakan Kelas (PTK). Desain penelitian menggunakan model Kemmis dan MC.Taggart yang terdiri dari empat komponen yaitu: "perencanaan, implementasi/pelaksanaan tindakan, observasi/pengamatan dan refleksi, dilakukan 2 siklus. Tiap siklus dilaksanakan perencanaan, tindakan, pengamatan dan refleksi dalam objek penelitian dan siklus berhenti pada siklus 2 jika siswa telah mencapai ketuntasan belajar secara klasikal.

Teknik pengumpulan data penelitian menggunakan : (1) tes hasil belajar berupa tes pilihan ganda untuk mengetahui hasil belajar pada ranah kognitif. (2) lembar observasi untuk mengetahui tingkat keterampilan proses sains siswa meliputi keterampilan mengamati, bertanya, memprediksi/ membuat hipotesis, mengkomunikasikan dan membuat kesimpulan. Observasi dilaksanakan pada saat proses pembelajaran berlangsung. Data penelitian yang diperoleh diolah dengan teknik analisis data sebagai berikut: (1) Untuk mengetahui tingkat penguasaan siswa terhadap materi pelajaran yang diajarkan, dilakukan perhitungan Persentase Perolehan Nilai (PPN) hasil belajar siswa yaitu dengan menggunakan rumus sebagai berikut:

PPN $=\frac{\text { Skor yang diperoleh siswa }}{\text { Skor maksimal }} \times 100 \%$

Kriteria tingkat penguasaan siswa terhadap materi pembelajaran adalah $90 \%-100 \%$ (sangat tinggi), 80\%-89\% (tinggi), 65\%-79\% (sedang), 55\%-64\% (rendah), 0\%-54\% (sangat rendah). (2) Untuk mengetahui ketuntasan belajar secara perorangan (individual) digunakan rumus:

$\mathrm{K}=\frac{\text { Skor yang diperoleh siswa }}{\text { Skor maksimal }} \times 100$

Dengan kriteria: $0<\mathrm{K}<85$ (tidak tuntas), $85 \leq \mathrm{K}<$ 100 (tuntas).

(3) Untuk mengetahui persentase siswa yang sudah tuntas belajar secara klasikal digunakan rumus : 


\section{$\mathrm{P}=\underline{\sum \text { siswa yang tuntas belajar }} \times 100 \%$ \\ $\Sigma$ seluruh siswa}

Berdasarkan ketuntasan dalam belajar klasikal, jika 85\% dari jumlah siswa di kelas sudah mencapai nilai $\geq 85$ maka keberhasilan belajar dikatakan sudah tuntas secara klasikal. (4) Untuk mengetahui tingkat keterampilan proses sains siswa digunakan katergori sebagai berikut: 3,1-4 (tinggi), 2,1-3 (sedang), 1,1-2 (rendah), 0-1 (sangat rendah). Indikator keberhasilan penelitian adalah apabila 85\% siswa memperoleh nilai KKM ( $\geq 85$ ). KKM di MAN 2 Model Medan adalah 85.

\section{HASIL DAN PEMBAHASAN}

Pada siklus I siswa yang hasil belajarnya mencapai nilai KKM hanya 16 orang dari 42 orang siswa di kelas XI IPA2 atau 38,10\%, sehingga penggunaan LKPD berbasis inkuiri di siklus I dapat dikatakan belum optimal. Penggunaan LKPD berbasis inkuiri harus ditingkatkan efektifitasnya pada siklus II untuk mencapai indikator ketercapaian.

Nilai rata-rata hasil belajar siswa pada siklus I untuk pretes 35 dan postes 75,5. Data tersebut dapat dilihat pada Gambar 1.

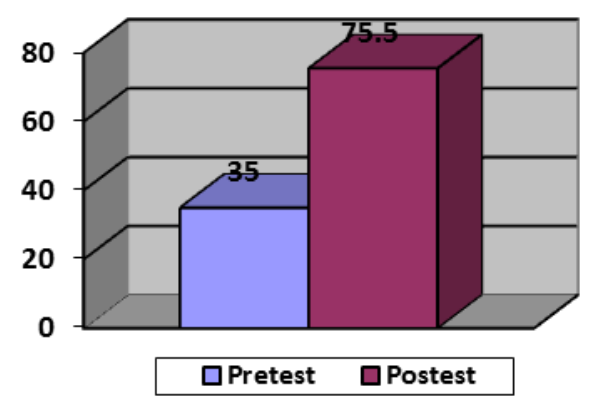

Gambar 1. Rata-rata Hasil Belajar Siklus I

Keterampilan proses sains siswa berturut-turut dari skor tertinggi sampai yang terendah adalah keterampilan mengamati (skor 3,3 dengan kategori tinggi), keterampilan komunikasi dan menyimpulkan (skor 3,2 dengan kategori tinggi), keterampilan bertanya (skor 2,9 dengan kategori sedang) dan keterampilan memprediksi (skor 2,2 dengan kategori sedang).. Hasil tersebut dapat juga dilihat pada Gambar 2.

Gambar 2. Keterampilan Proses Sains Siklus I

Pada siklus II siswa yang hasil belajarnya mencapai nilai KKM ada 36 orang siswa dari 42 orang siswa di kelas XI IPA2 atau ketuntasan klasikal $85,71 \%$ dengan rata-rata hasil belajar siswa 93,8, sehingga dikatakan tercapai ketuntasan klasikal.
Dapat dikatakan penggunaan LKPD berbasis inkuiri di siklus II dikatakan sudah optimal karena indikator keberhasilan dalam penelitian ini tercapai.

Terjadi peningkatan rata-rata hasil belajar siswa, demikian juga dengan persentase ketuntasan 
belajar secara klasikal. Perbandingan rata-rata hasil belajar siswa dan ketuntasan belajar siswa pada siklus I dan siklus II dapat dilihat pada Gambar 3. Terjadi peningkatan hasil belajar Biologi siswa baik rata-rata hasil belajar maupun ketuntasan belajar secara klasikal dengan menggunakan LKPD berbasis inkuiri dalam kegiatan pembelajaran Biologi siswa kelas XI IPA2 Model Medan.

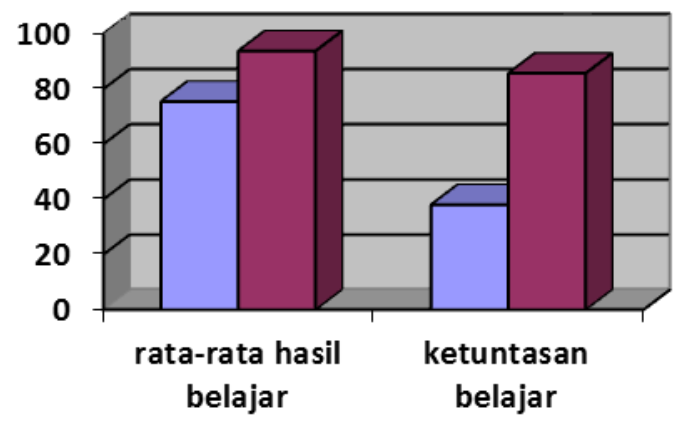

口Siklus I 口Siklus II

Gambar 3. Perbandingan Rata-Rata Belajar dan Ketuntasan Belajar Siklus I dan II

Pada siklus II, keterampilan proses sains siswa berturut-turut dari skor tertinggi sampai yang terendah adalah keterampilan mengamati (skor 3,7 kategori tinggi), menyimpulkan (skor 3,5 kategori tinggi), mengkomunikasikan (skor 3,1 katagori tinggi), bertanya (skor 3,0 kategori sedang) dan memprediksi (skor 2,5 kategori sedang). Perbandingan keterampilan proses sains pada siklus I dan II dapat dilihat pada Gambar 4 berikut ini.

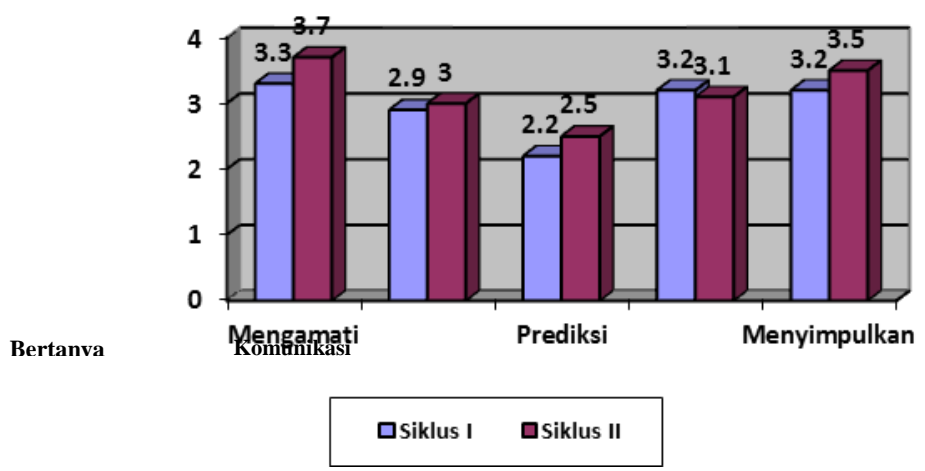

Gambar 4. Perbandingan Keterampilan proses sains Siklus I dan Siklus II

Dari Gambar 4 terlihat bahwa 4 dari 5 keterampilann sains di siklus II lebih baik dari pada siklus I. Hanya keterampilan mengkomunikasikan di siklus II sedikit lebih rendah dari siklus I, tetapi keterampilan mengkomunikasikan di kedua siklus tersebut sama-sama pada kategori tinggi.

Siswa yang sudah mencapai KKM pada siklus I berjumlah 16 orang siswa dari 42 orang siswa atau $38,10 \%$ siswa, dengan nilai rata-rata 75,5 . Siswa yang sudah mencapai KKM pada siklus II berjumlah 36 orang siswa dari 42 orang siswa di kelas tersebut atau $85,71 \%$, dengan nilai rata-rata
93,8. Dengan demikian peningkatan hasil belajar dari pretest dan postest I meningkat sebesar $38,10 \%$ siswa yang mencapai KKM. Sementara persentase siswa yang mencapai KKM pada siklus II juga meningkat sebesar $47,61 \%$ siswa yang lulus KKM dibandingkan jumlah siswa yang lulus pada siklus I dengan menggunakan LKPD berbasis inkuiri. Hasil penelitian ini sejalan dengan apa yang dinyatakan Daryanto (2014) bahwa penerapan pembelajaran inkuiri didalam proses pembelajaran selain berdampak positif pada keterampilan proses sains siswa, juga membantu mengembangkan 
kemampuan kognitif siswa. Karakteristik pembelajaran inkuiri yang melibatkan prosesproses kognitif potensial dalam merangsang perkembangan intelektual, khususnya keterampilan berpikir tingkat tinggi siswa.

Keterampilan proses sains siswa di siklus II juga meningkat dibandingkan keterampilan proses sains siswa di siklus I. Skor keterampilan mengamati di siklus । 3,3 (kategori tinggi) sedangkan di siklus II

3,7 (kategori tinggi). Skor keterampilan bertanya di siklus I 2,9 (kategori sedang) sedangkan di siklus II 3,0 (kategori sedang). Skor keterampilan prediksi di siklus I 2,2 (kategori sedang) sedangkan di siklus II 2,5 (kategori sedang). Skor keterampilan mengkomunikasi di siklus I 3,2 (kategori tinggi) sedangkan di siklus II 3,1 (kategori tinggi). Skor keterampilan menyimpulkan di siklus I 3,2 (kategori tinggi) sedangkan di siklus II 3,5 (kategori tinggi). Hasil tersebut sesuai dengan pendapat Rustaman (2005) bahwa dalam pembelajaran inkuiri terbimbing siswa diajak melakukan pencarian konsep melalui

kegiatan yang melibatkan pertanyaan, inferensi, prediksi, berkomunikasi, interpretasi dan menyimpulkan sehingga dalam pembelajaran inkuiri terbimbing melibatkan keterampilan proses sains. LKPD sebagai salah satu bahan ajar yang menjadi panduan dalam belajar mengacu pada langkah-langkah inkuiri sehingga keterampilan proses sains siswa dapat berkembang.

Skor keterampilan proses yang lebih tinggi pada siklus II disebabkan perbaikan di skenario pembelajaran. Pada siklus I guru terlebih dahulu menjelaskan materi secara singkat, setelah itu LKPD yang berbasis inkuiri dibagikan ke siswa, lalu secara berkelompok siswa mengerjakan LKPD tersebut dengan bantuan buku pegangan siswa. Pada siklus II sebelum guru menjelaskan materi, LKPD terlebih dahulu dibagikan ke siswa, kemudian guru memberikan arahan kepada siswa tentang LKPD tersebut, lalu guru menjelaskan materi dengan power point. Skenario pembelajaran di sklus II seperti itu dapat menyimpan/mengingat tugastugas di LKPD dalam pikiran siswa terlebih dahulu sebelum guru menjelaskan materi. Pada saat guru menjelaskan materi pembelajaran, siswa dapat mengarahkan/mensinkronkan materi yang dijelaskan guru dengan tugas-tugas dalam LKPD yang harus dikerjakannya, sehingga pada waktu mengerjakan LKPD siswa lebih mudah menyelesaikannya dengan baik. Otak/pikiran siswa dilatih untuk menemukan sendiri konsep dan fakta melalui proses ilmiah yang dipandu dengan LKPD inkuiri terbimbing. Sebagaimana pendapat Rustaman (2007), bahwa merancang pengalaman belajar sains terkait erat dengan pengembangan keterampilan proses sains karena rancangan belajar sains harus sesuai dengan hakikat sains sebagai produk ilmiah, proses ilmiah dan sikap ilmiah. Oleh karena itu, untuk dapat menerapkan pembelajaran yang dapat mengembangkan keterampilan proses sains siswa diperlukan LKPD berbasis inkuiri, hal ini dapat memunculkan hakikat sains secara seimbang. LKPD berbasis inkuiri sebagai salah satu bahan ajar yang menjadi panduan dalam belajar mengacu pada langkah-langkah inkuiri sehingga keterampilan proses sains siswa dapat berkembang. Pendapat Gulo dalam Trianto (2009) inkuri terbimbing merupakan kegiatan pembelajaran yang dirancang untuk melibatkan siswa secara langsung dalam proses ilmiah, sehingga mampu memahami produk dari proses sains berupa fakta dan konsep. Hasil penelitian lain yang sejalan dengan hasil penelitian ini adalah penerapan pembelajaran berorientasi saintifik seperti pembelajaran inkuiri, membuat proses belajar menjadi lebih menarik dan membuat peserta didik lebih antusias, dan secara langsung memberikan dampak pada hasil belajar yang lebih baik (Jaya dkk, 2014).

\section{KESIMPULAN}

Berdasarkan data hasil penelitian dan analisis data penelitian di atas dapat disimpulkan bahwa : (a) Penggunaan LKPD berbasis inkuiri dapat meningkatkan hasil belajar Biologi siswa di kelas XI IPA2 MAN 2 Model Medan T.P 2018/2019. Siswa yang sudah mencapai KKM pada siklus I berjumlah 16 orang siswa dari 42 orang siswa atau 38,10\% siswa, dengan nilai rata-rata 75,5. Siswa yang sudah mencapai KKM pada siklus II berjumlah 36 orang siswa dari 42 orang siswa atau $85,71 \%$, dengan nilai rata-rata 93,8. (b) Penggunaan LKPD berbasis inkuiri dapat meningkatkan keterampilan proses sains siswa pada mata pelajaran Biologi di kelas XI 
IPA2 MAN 2 Model Medan T.P 2018/2019. Skor keterampilan mengamati di siklus I 3,3 (kategori tinggi) sedangkan di siklus II 3,7 (kategori tinggi). Skor keterampilan bertanya di siklus I 2,9 (kategori sedang) sedangkan di siklus II 3,0 (kategori sedang). Skor keterampilan prediksi di siklus I 2,2 (kategori

\section{DAFTAR PUSTAKA}

Carin, A.A. (1997). Teaching Science through Discovery (Eighth ed). New Jersey: Prentice Hall.

Daryanto. 2014. Pendekatan Pembelajaran Saintifik Kurikulum 2013. Yogyakarta: GavaMedia

Jaya Gede Wiratma, Boas Patasik, Eka K.R.N Sembel, Lambang Subagiyo, M.Yunus. 2014. Penerapan Pendekatan Saintifik Melalui Metode Eksperimen Pada Pembelajaran Fisika Siswa Kelas X Mia 3 Sma Negeri 1 Tenggarong (Materi Suhu Dan Kalor). Jurnal Saintifika. [online]. Tersedia: http://jurnal.unej.ac.id/index.php/STF

Rustaman, N. (2005). Perkembangan Penelitian Pembelajaran Berbasis Inkuiri dalam Pendidikan Sains [Online]. Tersedia:

http://file.upi.edu/Direktori/SPS/PRODI.PENDIDIK AN_IPA/195012311979032 NURYANI_RUSTAMAN/PenPemlnkuiri.pdf. [9 September, 2012].

Rustaman, N. (2007). Keterampilan Proses Sains. Bandung: UPI. (online). (http://file. upi.edu/Direktori/SPS/PRODI.PENDIDIKAN_ IPA/195012311979032/NURYANI_ RUSTAMAN/KPSvsKG.pdf, diakses pada 10 Maret 2013; 21:10 WIB)

Trianto.(2009). Mendesain Model Pembelajaran Inovetif Progresif. Penerbit Kencana Prenada Media Group, Jakarta. sedang) sedangkan di siklus II 2,5 (kategori sedang). Skor keterampilan mengkomunikasi di siklus I 3,2 (kategori tinggi) sedangkan di siklus II 3,1 (kategori tinggi). Skor keterampilan menyimpulkan di siklus I 3,2 (kategori tinggi) sedangkan di siklus II 3,5 (kategori tinggi). 